\title{
Tax Revenue and Economic Growth in Nigeria
}

\author{
ASAOLU Taiwo Olufemi \\ Department of Management and Accounting, Faculty of Administration, \\ Obafemi Awolowo University, Ile- Ife, Osun State \\ OLABISI Jayeola ${ }^{\#}$ \\ Department of Accounting, Federal University of Agriculture, Abeokuta, Nigeria \\ AKINBODE Sakiru Oladele \\ Department of Economics, Federal University of Agriculture, Abeokuta, Nigeria \\ ALEBIOSU Omolabake Naimot \\ Department of Accounting, Federal University of Agriculture, Abeokuta, Nigeria
}

\#corresponding author.

\begin{abstract}
The study examined the relationship between tax revenue and economic growth in Nigeria. The study adopted a descriptive and historical research design; secondary data for twenty-two years (1994 -2015) were collected from various issues of the Central Bank of Nigeria (CBN) statistical bulletin and annual reports. Tax revenue as an independent variable was measured with Value Added Tax (VAT); Petroleum Profit Tax (PPT); Company Income Tax (CIT) and Custom and Excise Duties (CED) while the dependent variable was Economic Growth (EG) proxied by the Gross Domestic Product (GDP). Analysis was performed on data collected using Auto Regressive Distributed Lag (ARDL) Regression and other post estimations (Jarque-Bera test; Breusch-Godfrey LM and Ramsey Reset Test) to determine the existence of relationship between the variables. The results of the study showed that VAT and CED had a significant relationships with economic growth $(\mathrm{p}<0.05)$, while CIT has negative significant relationship with economic growth $(\mathrm{P}<0.05)$. However, PPT had no significant relationship with economic growth. The study concluded that the role of taxation in nation's building is irreplaceable. Taxation remains a strong socio political and economic tool for economic prosperity. It is therefore recommended that government should engage in a complete re-organization of tax administrative machinery to reduce incidence of tax evasion and avoidance to the barest minimum in order to improve tax revenue and bring more people and establishments into the tax net. Also, tax revenue should be judiciously utilized to provide enabling environment for business survival and economic growth in Nigeria.
\end{abstract}

Keywords: Value Added Tax, Petroleum Profit Tax, Company Income Tax; Custom and Excise Duties and Economic Growth 


\section{INTRODUCTION}

The principalobligation of every responsible government is the provision of adequate public goods and services that improvethe standard of living of citizens. The fulfillment of these responsibilities essentially depends on the quantum of revenue generated by the government through various means. Taxation is one of the viable sources of revenue generation to provideessential services for the generality of people living in a particular geographical area. Tax as a compulsory paymentimposed on individuals, groups, business or corporate bodies and properties are used to defray government expenditures. Extant literature such as Anyawu (1997) and Afuberon and Okoye, (2014) reveal that taxation generates funds to finance public goods, regulates production and consumption of goods and services, controls adverse economic conditions, protects infant industries and reduces income inequality among others. A tax system is a veritable tool that mobilizes a Nation's internal resources that create enabling environment to grow economy. When taxes are efficiently and effectively administered, there will be an increased revenue generation and citizens will expect deployment of such revenue toprovide amenities that enhancestandard of living. However, unqualified tax personnel and fraudulent activities of tax collectors pose great challenges to revenue generation as fraudulent tax collectorsforge and divert government revenue into personal pockets. Also, the inability of government to reciprocate the sacrifice of tax payment has induced tax payers to explore the loopholes in tax laws to avoid and evade tax payment, hence the continuous reduction in tax revenue generation.

In Nigeria, tax revenue has accounted for a small proportion of total revenue generated over the years compared withthe bulk of revenue generated by the Federal Government (Otu\&Adejumo, 2013). Records showed that decline in oil prices in recent times has led to decreased funds available for distribution among Federal, State and Local Governments in Nigeria (Afuberon\&Okoye, 2014). Hence, over-dependence on oil as a major source of revenue in Nigeria has become a serious set-back for sustainable economic growth. The fluctuation in oil prices in the international market has been a serious concern for Nigerians and government on the need to diversify the economy. It is noteworthy that globally, there is a paradigm shift to tax revenue as a better alternative source of revenue generation and the need for Nigerian government to generate adequate revenue from taxation has become a matter of urgency and importance (Afuberon\&Okoye, 2014). Hence, the inconsistent results of previous studies regarding the effect of tax revenue on economic growthprompts further investigationin Nigeria.

The main objective of this study is to examine the causal relationship between tax revenue and economic growth in Nigeria. Specifically, the study sought to examine the impact of value added tax on economic growth in Nigeria, assess the significant relationship between companies' income tax and economic growth in Nigeria, ascertain the significant influence of petroleum profit tax on economic growth in Nigeria, and, investigate the influence of custom and excise duty on economic growth in Nigeria. Findings and recommendations of this study are expected to be useful for government fiscal policy formulation and to other stakeholders in the financial sector of the economy.

\section{LITERATURE REVIEW}

Unegbu and Irefin, (2011) described tax as a compulsory levy imposed on the taxable income of everytaxable individual, companies, institutions or productsby the government within a particular jurisdiction, to defray expenditure on public goods. Taxation is the concept and science of imposing tax on taxable income of tax payers within a particular jurisdiction. The tax collected is used for common good of every citizen within the state for the production of certain services, which are considered to be of paramount importance to the wellbeing of the citizens (Enahoro\&Olabisi 2012). The above description of taxation underlines the main purpose of taxation which is to raise revenue to defray the cost of services provided by the government. It also includes reduction of inequalities arising from the distribution of wealth, to restrain certain types of consumption, to protect home industries and to control certain areas of the country's economy. Examplesof this include balance of payment, employment, savings, investment and productivity. According to Oladipupo and Ibadin, (2015) other purposes are to increase efficient productivity, increasethe services provided by the government, provision of employment, enhancement of modern technology the system and rationalization of terms and conditions of the economic system.

Tax is assessed in accordance with some reasonable rules of apportionment on persons or property within tax jurisdiction. Anyanwu (1997) defined tax revenue as a compulsory transfer or payment from private individuals, institutions or groups to the government. Jarkir (2011) asserted that tax is a contribution exacted by the state; it is a compulsory and unrequited transfer of resources from the private to the public sector, levied on the basis of predetermined criteria. The classical economists were of the view that the only objective of tax revenue was to generate revenue for the government. But with the change in circumstances and ideologies, the aim of taxes has

http://dx.doi.org/10.19085/journal.sijmd050701 
changed. These days apart from raising revenue, tax is levied to affect consumption, production and distribution with a view to achieving social welfare through economic development. According to Nzotta (2007), four key issues must be understood for tax revenue to play its functions in the society. Firstly, a tax is a compulsory contribution made by the citizens to the government and this contribution is for common use. Secondly, tax imposes a general obligation on the tax payers. Thirdly, there is a presumption that the contribution to the public revenue made by the tax payer may not be equivalent to the benefits received. Finally, a tax is not imposed on citizens by the government because it has rendered specific services to the citizens. Thus, it is evident that a good tax structure plays a multiple role in the process of economic development of any nation.

\section{Nigerian Tax Administration}

Appah (2010) posited that under the current Nigerian law, tax revenue is enforced by the three tiers of government, that is Federal, State, and Local Government Area with each having its sphere clearly spelt out in the Taxes and Levies (approved list for Collection) Decree, 1998. Successive governments have expressed concern about the low level of productivity of the Nigerian tax system. This has been attributed largely to the deficiencies in the tax administration and collection system, complex legislation, and apathy, especially on the part of those outside the tax net. This is because as a means of meeting expenditure requirements, many developing countries undertook tax reforms in the 1980s. However, most of these reforms focused on tax structure rather than tax administration geared towards generating more revenue from existing tax sources.

In the words of Unegbu and Irefin, (2011), the Nigerian tax system has undergone several reforms geared at enhancing tax administration with minimal enforcement cost. The recent reforms include the introduction of Taxpayer Identification Number (TIN), which became effective in February 2008, Automated Tax System that facilities tracking of tax positions, E-payment system which enhances smooth payment procedure and reduces the incidence of tax touts, enforcement scheme which engages special tax officers in collaboration with other security agencies to ensure strict tax compliance.

Section 8(a) of Federal Inland Revenue Service Establishment Act 2007 has led to an improvement in the tax administration in the country, thus, the integrated tax offices and authorities now have autonomy to assess, collect and record tax. Despite this improvement, there are still a number of contentious issues that require urgent attention such as appropriate tax authority to administer taxes, the issue of multiple taxesadministered by different levels of government which sometime imposes welfare cost and unavailability of data base, which contributes to tax avoidance in the country (Unegbu\&Irefin, 2011). Unegbuet.al added that the issue of corruption is perennial to the country and reduces the confidence and trust reposed on government by the tax payers to discharge their civic duty. The issue of infrastructural deficit is crucial and most facilities are often privately sourced, hence, taxpayers always question the rationale behind tax collection and consequently, develop a tendency to evade tax payment.

\section{Value Added Tax (VAT)}

The concept Value-Added Tax has been given different definitions by different authors and writers. According to Abata (2014) "Value-Added Tax is described as a consumption tax whereby the consumers bear the tax burden. He explained that tax burden is passed from the manufacturer to wholesaler to retailer and finally to the consumer who ultimately bear the burden. Ittherefore means that VAT can only be avoided by not buying and consuming the vat able goods or services. Similarly, a vatable person is one who trades in vat able goods and services for considerations. Olurofimi (2013) asserted that indirect tax imposed on every sale begins at the production and distribution cycle and culminates in sales to the consumers. He went further to create an impression that, consumers absorb VAT as part of sales prices, meaning that VAT is essentially a consumption tax collected, throughout the production chain. VAT is broadly based tax on consumption with few exceptions, levied on goods and services at the rate that varies from one country to another. Okoye and Gbegi (2013) added that Value Added Tax is a multistage tax imposed on the value added to goods and services as they proceed through various stages of production and distribution process and to services as they are rendered with itsburden eventually borne by the final consumer and collected at each stage of production and distribution chain.

\section{Petroleum Profit Tax (PPT)}

Petroleum Profit Tax Act 1959 as amended described petroleum profit tax as a liabilitywhere a company disposes off chargeable oil and gas. Disposal include delivery of chargeable oil to refinery, the tax is on the profit of the 
company from petroleum operation under the provision of PPTA in Nigeria. The petroleum operation as defined in the act, essentially involves petroleum exploration, development, production and sales of crude oil. Section 8 , of Petroleum Profit Tax Act (PPTA) states that every company engaged in petroleum operation is under an obligation to render return, together with properly annual audited account and computations, within a specified time after the end of accounting period. Fasoranti (2013) affirmed that PPT involves charging of tax on income accruing from petroleum operations. He noted that the importance of petroleum to Nigeria economy gives rise to the enactment of different laws regulating taxation of incomes from petroleum operations. Petroleum profit tax is a tax applicable to upstream operations in the oil industry as it is related to rent, royalties, oil mining prospecting and exploration leases. It is an important tax in Nigeria in terms of its contribution to total revenue as it contributes over $70 \%$ to government revenue and 95\% to foreign exchange earnings Kiabel (2009).Ilaboya (2012) hinted that the basis period for Petroleum Profit Tax (PPT) is the actual profit of the accounting period. This implies that, the basis period for any year of assessment is the same as the accounting period of the company.

\section{Company Income (CIT) Tax in Nigeria}

Appah (2010) submitted that Company Income Tax is payable by all incorporated entities in Nigeria on profits accruing in, derived from, brought into or received in Nigeria. It also includes taxes on the profits of non-resident companies carrying on business in Nigeria and is paid by both private and public limited liability companies. CIT was created by the Companies Income Tax Act (CITA) 1979 and has its root in Income Tax Management Act of 1961. It is one of the taxes administered and collected by the Federal Inland Revenue Service (FIRS), and the tax contributes significantly to the revenue profile of the government. Such profits shall be deemed to accrue in Nigeria wherever they have arisen (worldwide) and whether or not they have been brought into or received in Nigeria (Ugochukwu\&Azubike, 2015). These include profits in respect of any trade or business, rent on use of property, dividends, interest, royalty, discounts, charges, annuities, fees for services rendered and other sources of annual profits or gains. Company Income Tax Act in Nigeria is therefore collected from both Nigerian as well as foreign companies. Company income tax is one of the most important sources of revenue collection for the Government of Nigeria.

\section{Custom and Excise Duty}

Fasoranti, (2013) described Import duty as a levy on imports by custom authorities in Nigeria to raise revenue for the government and protect domestic industries from predator competitors abroad. Oladipupo and Ibadin (2015), Import duty is generally on the value of goods oron the weight, dimensions or some other criteria that are determined by the government. They are charged as a percentage of the value of import or a fixed amount of specific quantity (Fasoranti, 2013).Import duties are either fixed or calculated as a percentage of the product's value, which can change (Olurotimi, 2013). Sometimes, government may want to protect certain domestic product from foreign competition. One way of doing so is by imposing import duty, which makes foreign products more expensive, thus keeping the same domestic products more competitive (Ilaboya, 2012). Okoye and Gbegi (2013) held that government sometime imposes duties to hurt another country by making its exports more expensive. This is usually done as a retaliatory measure in a trade war. It is based on the value of goods called ad valorem duty or the weight, dimensions, or other criteria of the item such as its size (Oladipupo\&Ibadin, 2015).

Olurotimi, (2013) asserted that export duty is levied on the goods passing through a customs area with a route to another area or country. Point of taxation will be occurring from the date of export or from the movement of transferring goods from one country to another (Okoye\&Gbegi 2013). Export duties are no longer used to a great extent, except for certain mineral, petroleum, and agricultural products. Several resource-rich countries depend on export duties for much of their revenue (Ugochukwu\&Azubike, 2015). Export duties were common in the past; however, were significant elements of mercantilist trade policies. Inyiama, Ikechukwu and Madubuko, (2016) affirmed that an excise duty is the type of tax charged on goods produced within the country (as opposed to customs duties, charged on goods from outside the country). Though the collection of excise dutyaugments revenuegenerated by the government to provide public goods and services, however, over the years it has been used as an instrument of fiscal policy to stimulate economic growth (Olurotimi, 2013). 


\section{Tax revenue and Economic Growth}

A country's tax system is a major determinant of other macroeconomic indexes. Specifically for both developed and developing economies, there exists a relationship between tax structure and the level of economic growth and development. Undeniably, it has been argued that the level of economic development has a very strong impact on a country's tax base and tax policy objective varies with stages of development (Kiabel, 2009).Bhartia (2009) submitted that Growth is increased economic activities. Anyanwu (1997) summarized a country's economic growth as a long-term rise in capacity to supply increasingly diverse economic goods to its citizens. He added that the growth capacity is based on advancing technology, institutional and ideological adjustments.Economic growth indicates expansion of a country's potential Gross Domestic Product. Jarkir (2011) concluded that, at the early stage of economic development, the rate of growth in public expenditure will be very high because government provides basic infrastructural facilities and most these projects are capital intensive. Therefore, government's spending and investment in education, health, roads, electricity, and water are necessities that launch the economy from developing stage to take off stage of economic development to develop an egalitarian society (Bhartia, 2009).

\section{Theoretical Review \\ The expediency theory}

Otu and Adejumo (2013) argued that every tax proposal normally passes the test of practicality and is the only consideration for government authorityto choose a tax policy. This theory which is embedded in the canon of taxation explains the economy, effectiveness and efficiency of tax collection instruments. Taxation provides a powerful set of policy tools to the authorities and should be effectively used for remedying economic and social ills of the society such as income inequality, regional disparities, and unemployment (Afuberon\&Okoye 2014). Economic and social objective of the state is to put in place an effective tax system which should be relevant to the economic growth of a nation (Kiabel, 2009). Kiabel (2009) added that this proposition has a truth in it, since is useless to have a tax system which cannot be levied and collected efficiently. Since there are pressures from economic, social and political groups, and every group tries to protect and promote its own interests, hence, the authorities are often forced to reshape tax structure to accommodate these pressures. In addition, the administrative set up may not be efficient to collect the tax revenue at a reasonable cost. Ihenyen and Ebipanipre (2014) posited that taxation provides a powerful set of policy tools to the authorities and should be effectively utilizedfor remedying economic and social disturbance in the society such as income inequalities, regional disparities, unemployment, cyclical fluctuations.

\section{Empirical Review}

Edame and Okoi (2014) examined the impact of taxation on investment and economic growth in Nigeria from 1980 to 2010 using the ordinary least square method of multiple regression analysis to analyze the data which were sourced from the CBN statistical bulletin. The result of the analysis conformed to prior expectation because the parameter estimates of Company Income Tax have an inverse relationship with economic growth. Finally, the result showed that taxation is negatively related to the level of investment and GDP and is positively related to government expenditure in Nigeria. The study also observed that taxation is statistically significant factor influencing investment, GDP, and government expenditure in Nigeria. Abata (2014) studied the impact of tax revenue on Nigeria economy used descriptive survey design and chi square to analyze the data collected. The study found that tax revenue significantly impact on federal government budget implementation in Nigeria, tax evasion significantly affected government revenue in Nigeria, and lack of training on the part of tax officers significantly affected the generation of government revenue in Nigeria.

Ihenyen and Ebipanipre (2014) examined taxation as an instrument of economic growth in Nigeria. Using annual time series data sourced from the CBN statistical bulletin between 1980 and 2013. A linear model of corporate income tax, value added tax and economic growth were estimated by using the OLS technique. The empirical result suggests that the hypothesized link among corporate income tax, value added tax and economic growth indeed exist in the Nigerian context. Thus, the result offer tantalizing evidence that taxation is an instrument of economic in Nigeria. This conclusion points to the need for additional measures by government in ensuring that taxpayers do not avoid and evade tax so that income can be properly generated there from it. In addition, regulatory authorities charged with the sole responsibility of collecting tax should further be strengthened to enforce compliance by tax payers. Above all, the tax collected should be properly distributed so that economic growth can be properly harnessed. 


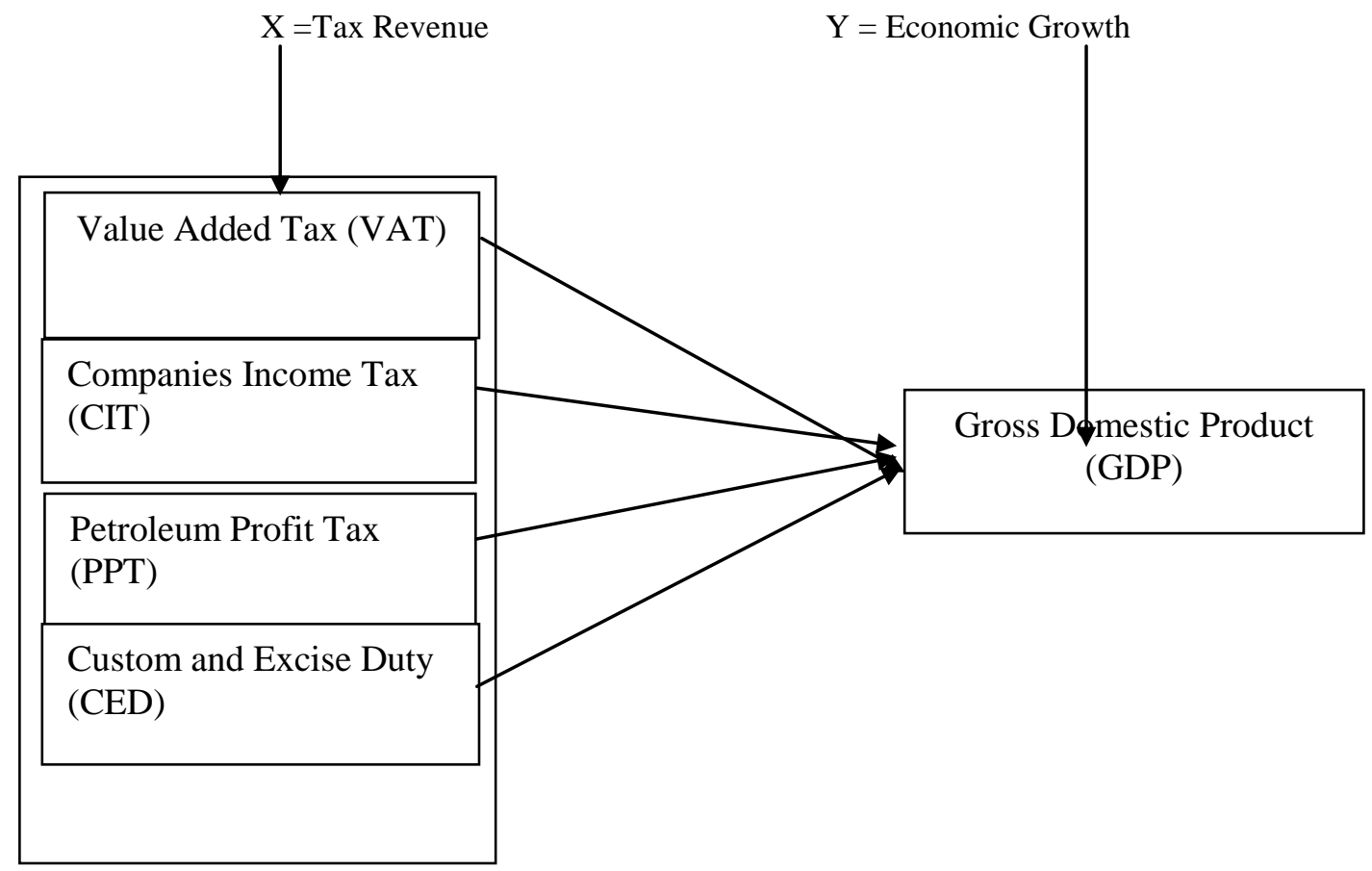

Source: Researcher's Operationalized Model (2017).

Fig 1: Operationalization of Variables

\section{METHODOLOGY}

This study adopted secondary data and historical research design in an attempt to determine the relationship between tax revenue generation and economic growth in Nigeria. The purpose for adopting this research design is to obtain a better understanding of the present through the evaluation of the past and intelligent prediction of the future. To show the relationship between tax revenue and economic growth, the study gathered data on tax revenue variables and economic growth. Data for this research comprised annual time series data from 1994 to 2015 collected from the Central Bank of Nigeria (CBN) statistical bulletin and annual reports as reported by the Federal Inland Revenue Service (FIRS) and the Federal Ministry of Finance. The GDP was used to evaluate the economic growth as it depicted the monetary value of all the finished goods and services produced in the country within a specified period and calculated annually while the independent variable which are the tax revenue in Nigeria was be proxied by Value Added Tax (VAT), a consumption tax levied on vat able products whenever value is added at each stage of production. This independent variable was measured using;

$\mathrm{Y}$ is Economic Growth

$\mathrm{X}$ is Tax Revenue

Economic Growth is measured by Gross Domestic Product (GDP)

Where Tax Revenue is measured by:

Value Added Tax isrepresented by $\mathrm{x}_{1}$;

CIT $=$ Companies Income Tax is represented by $x_{2}$;

$\mathrm{PPT}=$ Petroleum Profit Taxis represented by $\mathrm{x}_{3}$; and

$\mathrm{CED}=$ Custom and Excise Duty is represented by $\mathrm{x}_{4}$

Hence, $\mathrm{Y}=\mathrm{f}(\mathrm{X})$

$\mathrm{X}=\left(\mathrm{x}_{1}, \mathrm{X}_{2}, \mathrm{X}_{3}, \mathrm{X}_{4}\right)$

$\mathrm{Y}=\mathrm{f}\left(\mathrm{x}_{1}, \mathrm{x}_{2}, \mathrm{x}_{3}, \mathrm{x}_{4}\right)$

$\mathrm{GDP}_{\mathrm{t}}=\beta_{0}+\beta_{1} \mathrm{VAT}_{\mathrm{t}}+\beta_{2} \mathrm{CIT}_{\mathrm{t}}+\beta_{3} \mathrm{PPT}_{\mathrm{t}}+\beta_{4} \mathrm{CED}_{\mathrm{t}}+\mathrm{e}_{\mathrm{t}}$ 
$\beta_{0}=$ constant

$\beta_{1-4}=$ co-efficient of independent variable

$\mathrm{e}=$ error term

$\mathrm{t}=$ time series variable from $1 \ldots 22$

\section{Results and Discussion}

\section{Pre- estimation}

Below is the descriptive statistics and graphical analysis of the time series employed in the study. The essence was to give a cursory review of the statistical properties and trends of the variables employed.

\section{Descriptive Statistics}

The descriptive statistics depicted the qualities of data obtained and used for the estimation. This knowledge assistedin the choice ofappropriate methodology for estimation. The table 1 presents the summary of the descriptive statistics of the study variables.

Table 1 highlighted some of the statistical properties of selected variables for the study, the variables included: Real Gross Domestic Product (RGDP), Value Added Tax (VAT), Petroleum Profit Tax (PPT), Company Income Tax (CIT) and Custom and Excise Duty (CED). Between 1994 to 2015, Gross Domestic Product (GDP) at constant market price averaged approximately $\$ 39.6$ Trillion, total Value Added Tax (VAT) collected by the Federal Inland Revenue Service (FIRS) for the period averaged approximately $\$ 299.324$ Billion, Petroleum Profit Tax (PPT) for the period considered was approximately $\$ 1$ 15Trillion on the average, Company Income Tax (CIT) on the was \$352.852 Billion and Custom and Excise Duty (CED) averaged \$235.657 Billion. The table also revealed that all the series of the variables selected are positively skewed. The kurtosis statistics indicated that all the series were platykurtic (lowly peaked) as the statistics were below three (the threshold), implying that these series had higher tendency of having outliers. The essences of these two tests were to determine whether series employed followed normal distribution. However, these two tests were not individually sufficient in defining the distribution of the series employed, hence the need for Jarque Berra test. The test indicated that all the series were normally distributed (Table 1).

Table 1: Descriptive Statistics of the study variables

\begin{tabular}{cccccc}
\hline & RGDP & VAT & PPT & CIT & CED \\
& $\mathbf{N}^{\prime} \mathbf{0 0 0 , 0 0 0}$ & $\mathbf{N}^{\prime} \mathbf{0 0 0 , 0 0 0}$ & $\mathbf{N}^{\prime} \mathbf{0 0 0 , 0 0 0}$ & $\mathbf{N}^{\prime} \mathbf{0 0 0 , 0 0 0}$ & $\mathbf{N}^{\prime} \mathbf{0 0 0 , 0 0 0}$ \\
\hline Mean & 39600000 & 299323.7 & 1483032. & 352852.4 & 235657.2 \\
Median & 38500000 & 168800.0 & 1220000. & 146150.0 & 206300.0 \\
Maximum & 69780692.7 & 795600.0 & 4365400. & 1207300. & 566200.0 \\
Minimum & 20174494.1 & 7260.800 & 42802.70 & 12274.80 & 18294.60 \\
Std. Dev. & $1.75 \mathrm{E}+13$ & 289802.6 & 1403679. & 386169.9 & 167266.7 \\
Skewness & 0.359474 & 0.665640 & 0.718928 & 0.912963 & 0.577773 \\
Kurtosis & 1.652620 & 1.859047 & 2.279083 & 2.429416 & 2.253470 \\
Jarque-Bera & 2.137959 & 2.817909 & 2.371557 & 3.354606 & 1.734878 \\
Probability & 0.343359 & 0.244399 & 0.305508 & 0.186877 & 0.420026 \\
Sum & $8.71 \mathrm{E}+14$ & 6585122. & 32626702 & 7762753. & 5184459. \\
Sum Sq. Dev. & $6.40 \mathrm{E}+27$ & $1.76 \mathrm{E}+12$ & $4.14 \mathrm{E}+13$ & $3.13 \mathrm{E}+12$ & $5.88 \mathrm{E}+11$ \\
Observations & 22 & 22 & 22 & 22 & 22 \\
\hline
\end{tabular}

Source: Author's computation (2017) 


\section{Graphical Analysis}

Graphical illustration showed the movement, trends and fluctuations in the series. The figures below showed the graphical illustration of the relevant variables.

Figure 1 showed the trend in Real Gross Domestic Product (RGDP) in Nigeria, the graph showed that the values hovered around N20,000 billion and N70,000 billion within the periods under consideration. Though, there were fluctuations, it was shown that the GDP began to increase as indicated by the upward trend of the graph.

Figure 2 revealed that VAT revenue was increasing since its inception; this could be as a result of increased production and value adding activities in Nigeria. However, it has been declining in the past few years. Figure 3 showed that Petroleum Profit Tax (PPT) has been fluctuating; this may be due to the perceived instability in the production of petroleum in Nigeria. It reached its peak in 2012 and has been falling subsequently. Figure 4 indicated that there has been upward movement in Company Income Tax (CIT) within the periods under consideration. It has increased over time, reached its peak in 2013 and has been declining in the subsequent years. Figure 5 showed Custom and Excise Duty collected from 1994 to 2015, the revenue has not been stable as depicted by the graph.

\section{Figures 1-5: Graphical illustration of study variables}

\section{Real GDP (\#'billion)}

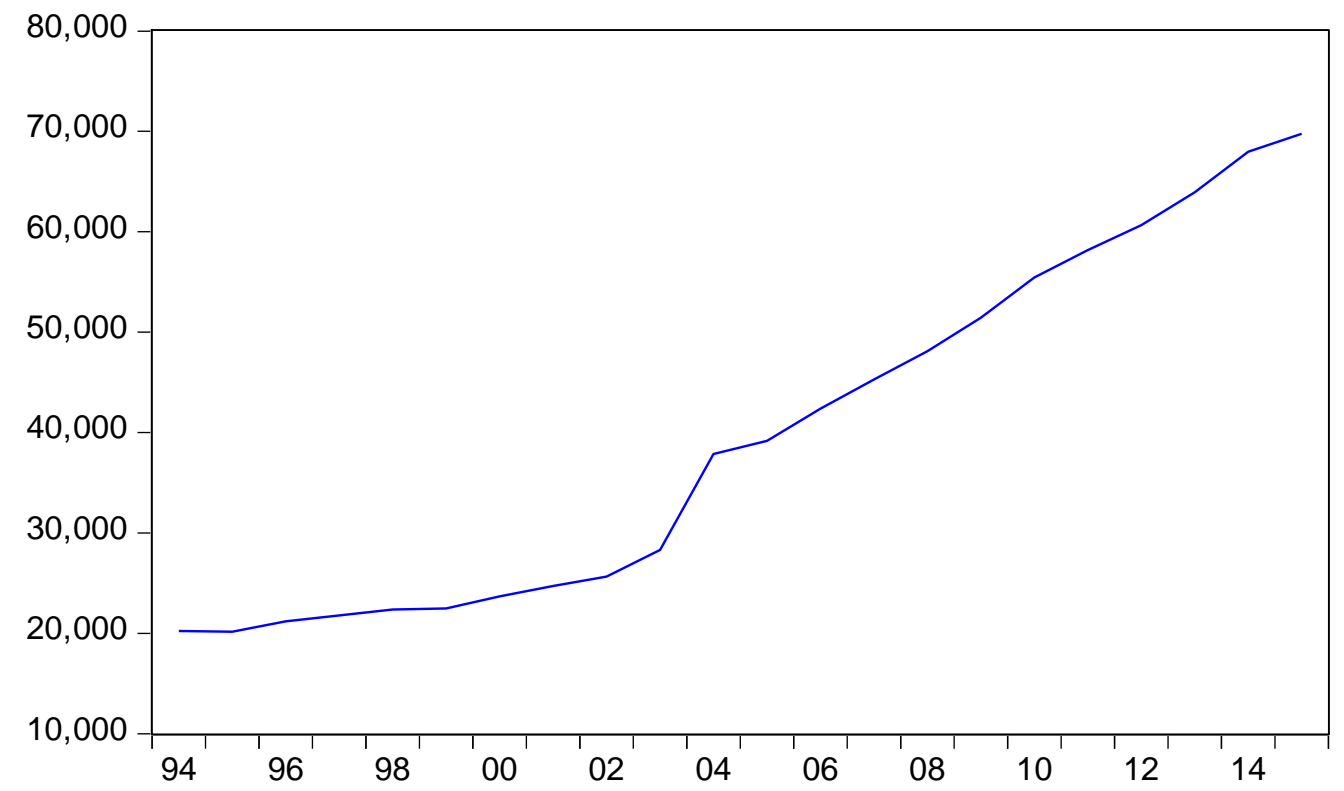

Figure 1: Real Gross Domestic Product (N' billion) 
VAT' 000,000

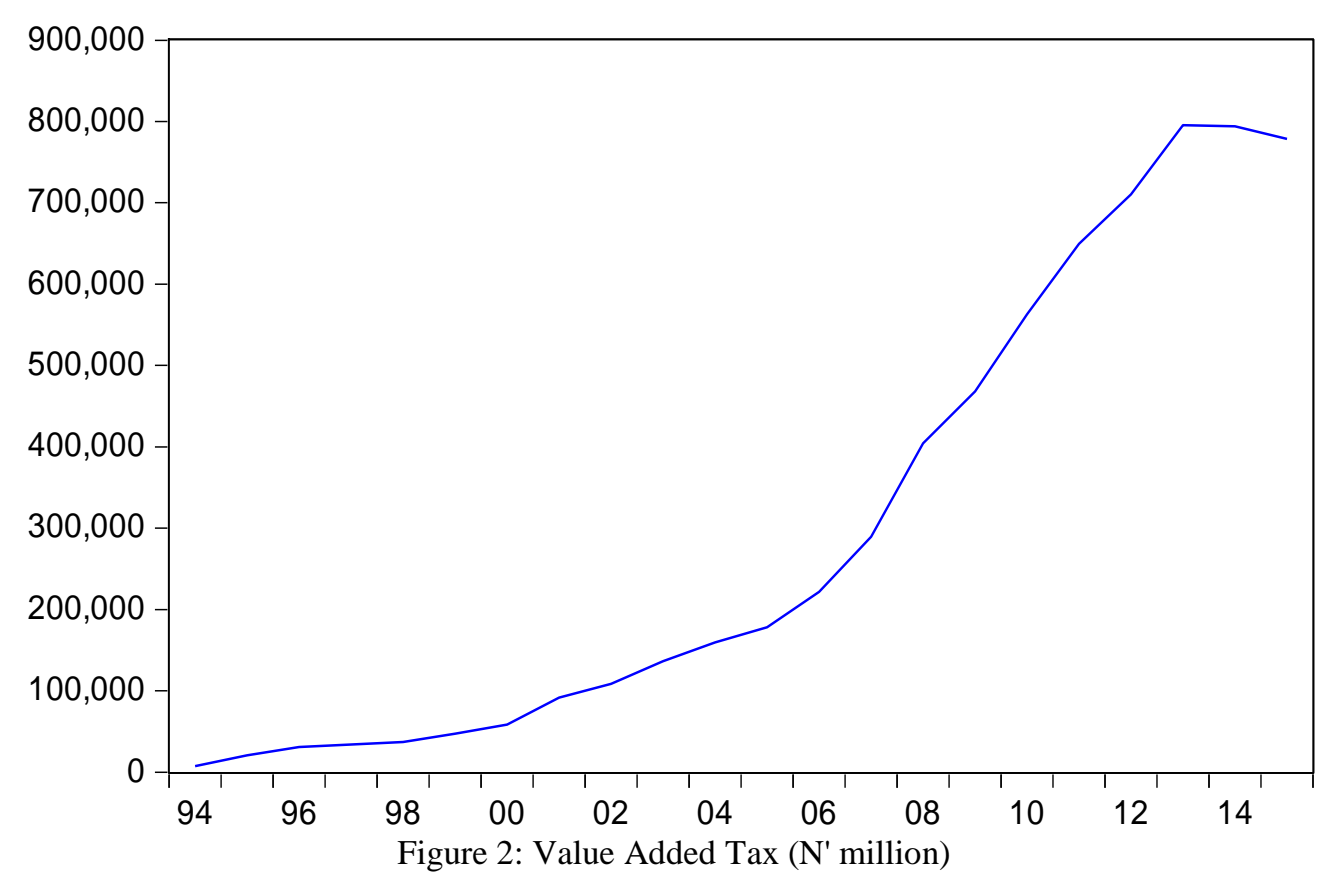

PPT'000,000

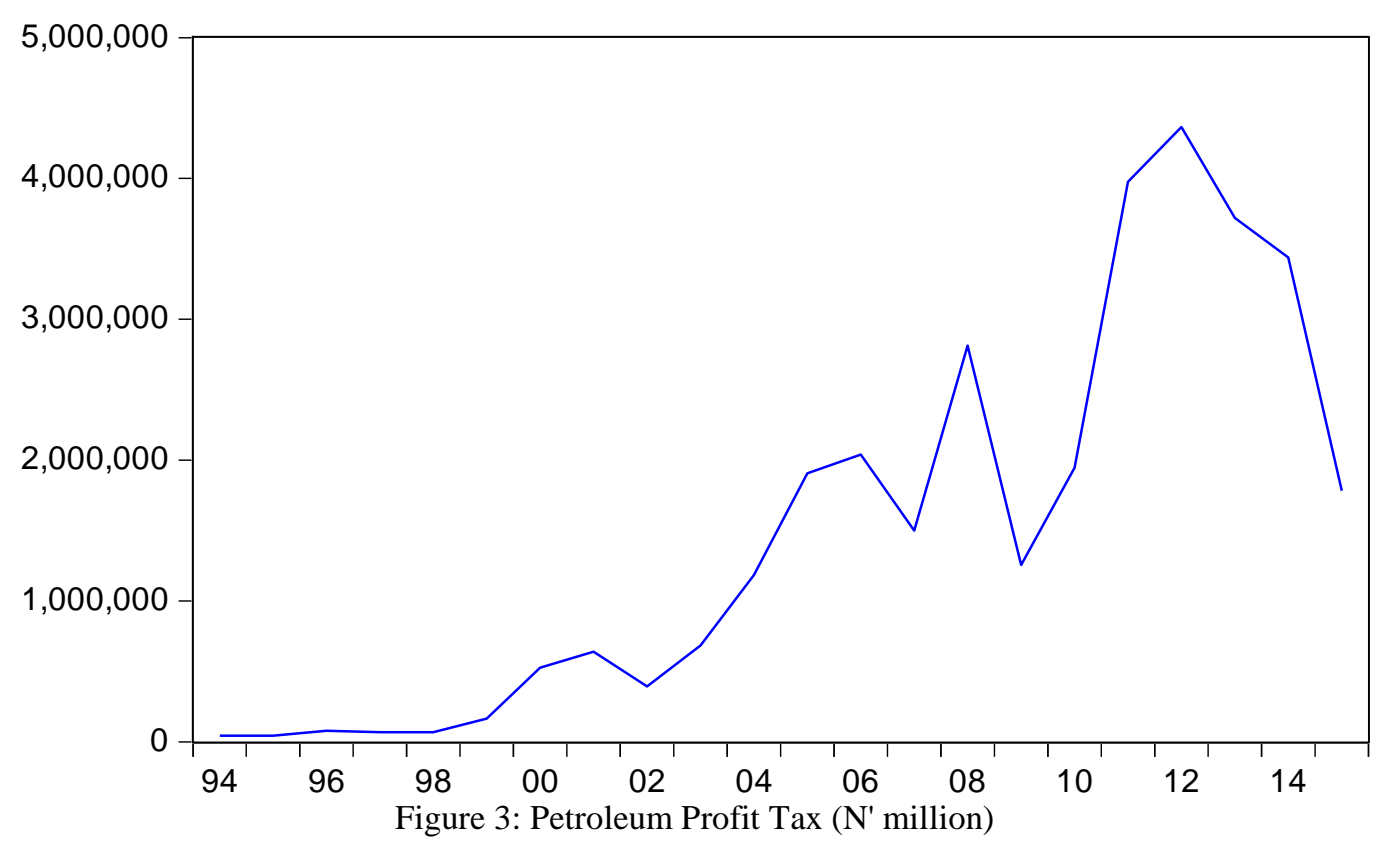




\section{CIT' 000,000}

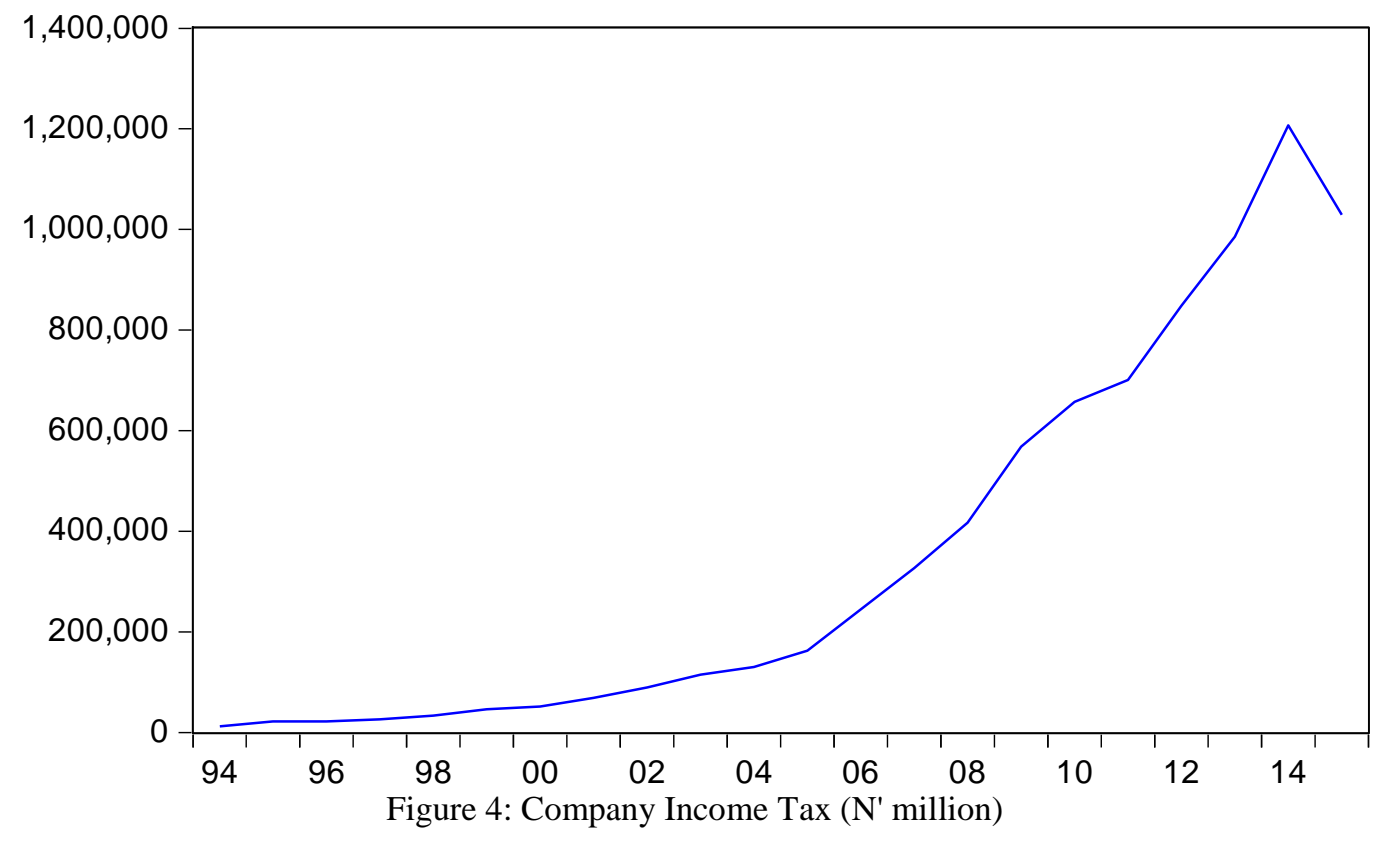

CED'000,000

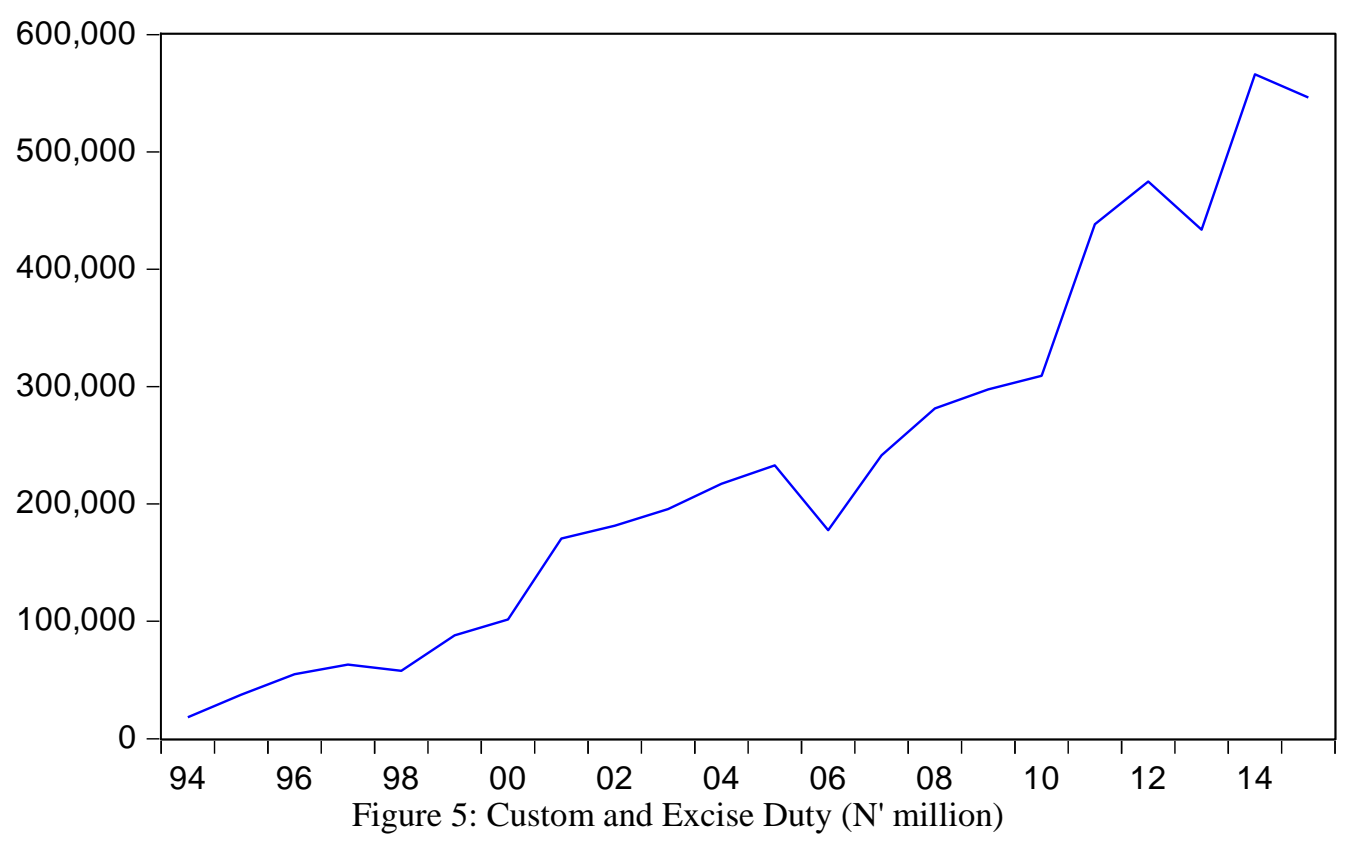

Source: Author's compilation (2017)

\section{Stationarity of Study Variables}

The unit root test (Table 2) revealed that not all the series under investigation were stationary, as the null hypothesis that the series of each of these variables with a unit root cannot be rejected at any chosen level of significance (1\%, $5 \%$, and $10 \%$ ) but could only be rejected after a difference of one. The series of Real Gross Domestic Product, Company Income Tax and Petroleum Profit Tax were all stationary at first difference, while Value Added Tax and 
Custom and Excise Duty were stationary at level. These results implied that running a regression analysis on these variables using Ordinary Least Square (OLS) Regression Technique would generate spurious results as some of the Traditional Least Square assumptions had been violated. However, before proceeding to the estimation proper, it was expedient to determine the long run relationship among these variables.

The unit root test conducted above indicated that some of the variables were stationary at level $\mathrm{I}(0)$ while some variables became stationary at first difference I(1). Owing to these facts, the Engle-Granger single equation cointegration technique became inappropriate to detect the presence of long run relationship among the variables as it was premised on stationary series or I(1) series alone. Auto Regressive Distributed Lag (ARDL) bound test was employed.

Table 2: Results of the Unit Root Test using the Augmented Dickey Fuller (ADF) Method

\begin{tabular}{|c|c|c|c|c|c|c|c|}
\hline \multirow[t]{2}{*}{ VARIABLES } & \multicolumn{3}{|c|}{ LEVEL } & \multicolumn{3}{|c|}{ FIRST DIFFERENCE } & \multirow[t]{2}{*}{ I (d) } \\
\hline & None & Intercept & $\begin{array}{l}\text { Intercept } \\
\text { and trend }\end{array}$ & None & Intercept & $\begin{array}{l}\text { Intercept } \\
\text { and trend }\end{array}$ & \\
\hline LGDP & 4.641 & 0.201 & -2.155 & $-2.224 * *$ & $-3.919 * * *$ & $-3.759 * *$ & I (1) \\
\hline LVAT & 3.210 & $-3.722 * *$ & $-3.955 * *$ & ------ & ------- & ------ & $\mathrm{I}(0)$ \\
\hline LCIT & -1.029 & -1.900 & -1.029 & $-2.662 * *$ & $-4.874 * * *$ & $-5.06 * * *$ & I (1) \\
\hline LPPT & 1.4791 & -1.7440 & -1.1116 & $-3.639 * * *$ & $-3.989 * * *$ & $-3.857 * *$ & I (1) \\
\hline LCED & 3.1246 & $-3.074 * * *$ & $-3.793 * *$ & ------ & ------- & ------ & I $(0)$ \\
\hline
\end{tabular}

Source: Author's compilation (2017)

\section{Co-integration Test}

The ARDL Bound test results reported in Table revealed that the $\mathrm{F}$ - statistics was below the lower critical bound at $10 \%$ level of significance. Thus, it was concluded that there was no long run relationship among the variables considered; therefore a short run (dynamic) model was estimated.

Table 3: ARDL Bound Test for co-integration

\begin{tabular}{llc}
\hline Test Statistics & Value & $\mathrm{K}$ \\
F-Statistics & 1.360568 & 4 \\
\hline
\end{tabular}

Critical Value Bounds

\begin{tabular}{lll}
\hline Significance & I0 Bound & I1 Bound \\
\hline $10 \%$ & 3.03 & 4.06 \\
$5 \%$ & 3.47 & 4.57 \\
$2.5 \%$ & 3.89 & 5.07 \\
$1 \%$ & 4.4 & 5.72 \\
\hline
\end{tabular}

Source: Author's compilation (2017)

Short-run Relationships between Tax Revenue and Economic Growth in Nigeria

Table 4 revealed that Value Added Tax (VAT) and Custom and Excise Duties (CED) exerted a positive influence on Real Gross Domestic Product (RGDP) in Nigeria, while Company Income Tax (CIT) affected the Real Gross Domestic Product (RGDP) negatively. It implied that as the amount of tax revenue collected from Value Added Tax, and Custom and Excise Duty increases, the Real Gross Domestic Product increases. More so, as Company Income Tax (CIT) increased, Real Gross Domestic Product (RGDP) reduced.

The result further indicated that for every $1 \%$ positive change in Value Added Tax (VAT), there was a cumulative positive change of $0.46 \%$ in Real Gross Domestic Product (RGDP), and this effect was statistically significant at $5 \%$. Also, a $1 \%$ change in Custom and Excise Duty (CED), resulted in a $0.0013 \%$ cumulative positive change in RGDP. Whereas, the same 1\% change in Company Income Tax (CIT) resulted in $0.37 \%$ negative change in RGDP. 
Although, it was shown that the amount of VAT received did affect the RGDP significantly at the 5\% chosen level of significance, Custom and Excise Duty (CED) and Company Income Tax (CIT) were also significant determinant of Economic Growth. Results showed that there were positive significant relationships between Value Added Tax, Custom and Excise Duty and Economic Growth, while a negative significant relationship existed between Company Income Tax and Economic Growth. Petroleum Profit Tax did not significantly impact Economic Growth.

Furthermore, the Adjusted $\mathrm{R}^{2}$ as shown in the table was 0.988 which revealed that the independent variables (VAT, CIT, PPT, and CED) can conveniently explain or account for the variations in RGDP with about $98.8 \%$ while the remaining $1.2 \%$ would be explained by other factors affecting economic growth which were not included in the model estimated.

Durbin Watson statistics was conducted in order to ascertain the presence or otherwise of autocorrelation in the model. The statistic value of 2.54 indicated that there was no autocorrelation in the model.

The F-statistic result indicated that regression model used in the study was good and fit for predictive purposes. Fstatistics was 160.8493 significant at 1 percent indicating that the overall model applied can statistically predict the dependent variable.

Table 4: Short Run Model for Tax Revenue and Economic Growth Dependent Variable: Log (RGDP)

\begin{tabular}{llll}
\hline \multicolumn{2}{l}{ Short Run (Dynamic) Model } & & \\
Variables & Coefficient & Standard Error & t-statistics \\
\hline DLog (VAT) & 0.139679 & 0.222661 & 0.627317 \\
DLog (VAT (-1)) & $0.538751^{* *}$ & 0.225647 & 2.387582 \\
DLog (VAT (-2)) & $-0.222025^{*}$ & 0.101681 & -2.183549 \\
DLog (PPT) & 0.058638 & 0.032281 & 1.816501 \\
DLog (CIT) & $-0.367060^{*}$ & 0.189980 & -1.932095 \\
DLog (CED) & $-0.283104^{* *}$ & 0.117760 & -2.404075 \\
DLog (CED (-1)) & $-0.215746^{*}$ & 0.111979 & -1.926658 \\
DLog (CED (-2)) & $0.500152^{* *}$ & 0.086436 & 2.315616 \\
R - Squared & 0.994436 & & \\
Adjusted R-squared & 0.988253 & & \\
F-statistics & $160.8493^{* * *}$ & & \\
Durbin-watson statistics 2.54 & & \\
\hline \multicolumn{2}{l}{ Source: Author's computation $(2017)$} & \\
$* * * * * *$ indicates significance level at $10 \%, 5 \%$, and $1 \%$ respectively. &
\end{tabular}

\section{Post Estimation}

The diagnostic test results reported in table 5 showed that the estimated models satisfied all the assumptions of the classical linear regression model; hence, the estimate obtained was reliable, consistent, efficient and suitable for forecasting and predictions. The result indicated that the error series of the model estimated has time invariant variance, as the null hypothesis of homoscedasticity cannot be rejected at 5\% significance level. The error series generated from the estimated model also satisfied the normality assumption as the JarqueBera Test showed that the null hypothesis of the series being normally distributed could not be rejected at 5\% significant level. BreuschGodfrey LM test was adopted to determine if the error series auto correlated. The test's null hypothesis was that no auto correlation existed and the null hypothesis could not be rejected at 5\% level of significance. In order to determine if the model was well specified, Ramsey RESET Test was adopted to conduct linearity test on the model with null hypothesis that the model was linear. The null hypothesis could not be rejected at $5 \%$ level of significance. Thus, the linearity of the model was confirmed. 
Table 5: Post Estimation Diagnosis Results

\begin{tabular}{lll}
\hline Test & \multicolumn{1}{c}{ Results } & probability \\
\hline Arch- LM & F- statistics & 0.99 \\
Jarque-Bera & $1.24 \mathrm{E}-04$ & 0.18 \\
Breusch - Godfrey LM & 3.42 & 0.42 \\
Ramsey Reset Test & 0.99 & 0.08 \\
\hline
\end{tabular}

Source: Author's computation (2017)

\section{CONCLUSION AND RECOMMENDATIONS}

The results obtained from the test of hypotheses carried out and review of extant literature showed that value added tax, company income tax, petroleum profit tax and customs and excise duty have positive significant impact on the economic growth in Nigeria.The study concludedthat Nigerian government should provide social amenities tothe nooks and crannies of the country as this will boost the level of tax compliance.To enhance the tax base of government, employment opportunities should be created and a good environment for entrepreneurship and innovation to thrive must be provided.Also the government should engage in a complete re-structuring of tax administrative machineries in order to reduce problems of tax evasion and avoidance to the barest minimum.To ensure sustainable economic development, generated tax revenue must be sufficient, efficiently and judiciously utilized. Government should pay attention to building trust in tax accountability, ensuring that promises made to the citizens are maximally delivered. Provision of facilities that provide comfortand improve well-being of citizens must be given attention by the government. The study recommended that the culture of good governance should be embraced by the government so as to secure the loyalty of the populace.

\section{REFERENCES}

[1]. Abata, M. A. (2014). The impacts of tax revenue on Nigerian economy.Journal of policy and Development Studies. 9(1),109-123.

[2]. Afuberon, I. R., \&Okoye, G. A. (2014).The effect of tax compliance on economic growth and development in Nigeria, West-Africa.British Journal of Arts and Social Sciences. 11(2).233-256

[3]. Angus, O. U., \&David, I. (2011). Impact of VAT on economic development of emerging Nations . Journal of Economics and International Finance, 3(8), 492-503.

[4]. Anyanwu, J.C., (1997). Nigerian Public Finance. Joanne Educational Publishers, Onitsha

[5]. Bariyima, M. O. (2008). Tax revenue and economic development in Nigeria.A macro econometric approach.Academic Journal of Interdisciplinary Studies. 1(2), 211-223.

[6]. Edame, M. A.,\&, Okoi, J. R. (2014). Impact of tax on investment and economic growth in Nigeria.Journal of Public Economics.8(2), 27-44.

[7]. Enegbu, E. C., Akujuobi, L. E.,\&Appah, E. (2011). An empirical study on the causality between economic growth and tax revenue in Nigeria.Current Research Journal of Economic theory. 4(2), 29-38.

[8]. Fasoranti, M. M. (2013) Tax productivity and economic growth.Lorem Journal of Business and Economics. 1(1), 1-10.

[9]. Ihenyen, C. J., \&Ebipanipre, E. G. (2014). Taxation as an instrument of economic growth: The Nigerian perspective. Journal ofInformation and Knowledge Management 4(12), 49-53.

[10]. Ilaboya, O. J. (2012). Indirect tax and economic growth.International Journal of Finance and Accounting, 3(11), 319-327.

[11]. Inyiama, O. I., \&Ubesie, M. L. (2016). Effect of value added tax, custom any excise duties on Nigeria economic growth. International Journal of Managerial Studies and Research, 4(10).234-242

[12]. Jakir, K. (2011). Role of tax revenue in economic development.Journal of Accounting and Tax Revenue. 3(5), 91104.

[13]. Joseph, U. M., Ikechukwu, I. O.,\& Amah, K.O. (2016).An assessment of the causal relationship between economic growth and indirect taxes in Nigeria. International Journal of Development and Economic Sustainability, 4(5), 56-65.

[14]. Kiabel, B. D. \&Nwokah, N. G. (2009).Boosting revenue generation by governments in Nigeria. The tax consultant's option revisited. European Journal of Social Sciences 8(4). 342- 254

[15]. Ofoegbu, G. N., Akwu, D. O., \& Oliver, O. (2016). Empirical analysis of the effect of tax revenue on economic development of Nigeria.International Journal of Asian Social Science, 6(10), 604-613.

[16]. Okafor, R. G. (2012). Tax revenue generation and Nigerian economic development. European Journal of Business and Management. 4(19), 49-56. 
[17]. Okoye, E. I., \&Gbegi, D. O. (2013). Effective value added tax: An imperative for wealth creation in Nigeria. Global Journal of Management and Business Research, 13(1), 231143.

[18]. Enahoro J. A., \&Olabisi, J. (2012).Tax administration and the revenue generation of Lagos State, Nigeria.Research Journal of Finance and Accounting, 3(5), 133-139.Oladipupo, T. O., \&Ibadin, C. S. (2015).Impact of tax revenue on economic growth inNigeria, European Journal of Economics, Finance and Administrative Sciences.48(12), 123-134.

[19]. Olurotimi, M. O, (2013).The impact of indirect tax revenue on Nigerian economy.Journal of Policy and Development Studies. 9(1), 109-121.

[20]. Otu, O. H., \&Adejumo, T. O. (2013).The effects of tax revenue on economic growth in Nigeria.International Journal of Humanities and Social Science Invention. 2(6),16-26

[21]. Unegbu, A. O., \&Irefin, D. (2011).Impact of VAT on economic development of emerging Nations.Arabian Journal of Business and Management Review. 1(9).

[22]. Ugochuwkwu, O. H., Okpe, I., \& Amah T. (2016).Causal relationships between indirect taxes and economic growth in Nigeria.International Journal of Finance and Accounting. 3(8),99-113.

[23]. Umeora, C. E. (2013). The effects of value added tax on the economic growth of Nigeria. Journal of Economies and Sustainable Development, 4(6), 275-282. 